\title{
ORIGINAL
}

\section{Hypoglycemia due to Ectopic Secretion of Insulin-like Growth Factor-I in a Patient with an Isolated Sarcoidosis of the Spleen}

\author{
YUIKo OGIWARA ${ }^{1)}$, SEIJIRo MORI ${ }^{1)}$, MizUKI IWAMA ${ }^{2)}$, MotoJI SAWABE ${ }^{3)}$, MinORU TAKEMOTO ${ }^{4}$, \\ NobUO KANAZAWA ${ }^{5)}$, KoH FURUTA ${ }^{6}$, IZUMI FUKUDA ${ }^{7)}$, YosHITAKA KONDO ${ }^{2)}$, YoshIYUKI KIMBARA ${ }^{1)}$, \\ Yoshiaki TAMURA ${ }^{1)}$, YUKo CHIBA ${ }^{1)}$, ATSUSHI ARAKI ${ }^{1)}$, KOUTARO YOKOTE ${ }^{4}$, NAOKI MARUYAMA ${ }^{2)}$ AND \\ HIDEKI ITO ${ }^{1)}$ \\ 1) Department of Diabetes, Metabolism and Endocrinology, Tokyo Metropolitan Geriatric Hospital, Tokyo, Japan \\ ${ }^{2)}$ Molecular Regulation of Aging, Research Team for Functional Biogerontology, Tokyo Metropolitan Institute of Gerontology, \\ Tokyo, Japan \\ ${ }^{3)}$ Department of Pathology, Tokyo Metropolitan Geriatric Hospital, Tokyo, Japan \\ 4) Department of Clinical Cell Biology and Medicine, Chiba University Graduate School of Medicine, Chiba, Japan \\ ${ }^{5)}$ Department of Surgery, Tokyo Metropolitan Geriatric Hospital, Tokyo, Japan \\ 6) Department of Psychiatry, Tokyo Metropolitan Geriatric Hospital, Tokyo, Japan \\ ${ }^{7)}$ Department of Medicine, Institute of Clinical Endocrinology, Tokyo Women's Medical University, Tokyo, Japan
}

\begin{abstract}
Hypoglycemia is reported to be one of the manifestations of a patient with hypothalamic sarcoid infiltrates due to impaired counter-regulation of glucose. But, without hypothalamic lesion, patients with sarcoidosis would not be expected to have hypoglycemia. We recently identified a patient with an isolated sarcoidosis of the spleen who had experienced frequent fasting hypoglycemia which completely disappeared after splenectomy. During hypoglycemia, serum insulin was undetectable. Endocrinological examination revealed no abnormality. The objective was to investigate whether the patient's hypoglycemia was due to ectopic secretion of an insulin-mimetic factor by the splenic sarcoidosis. Serum insulin-like growth factor-I (IGF-I) and IGF-II were measured by RIA. Serum visfatin and free IGF-I were by ELISA. A high molecular weight form of IGF-II, termed "big" IGF-II, was identified by Western blotting. Tissue IGF-I was quantified by real time RT-PCR after RNA extraction. Before operation, total and free serum IGF-I, serum IGF-II and serum visfatin were within reference range. Big IGF-II was not detected in patient's serum extract. After operation, hypoglycemia did not recur and serum insulin returned to normal, while serum IGF-I decreased by half the preoperative level. RT-PCR revealed that mRNA level of IGF-I in the sarcoidosis tissue was about 1.8-fold greater than that in the normal spleen tissue. These data suggest that ectopic secretion of IGF-I by the splenic sarcoidosis and its direct access to the liver via the portal vein might cause fasting hypoglycemia mainly by suppressing hepatic gluconeogenesis.
\end{abstract}

Key words: Hypoglycemia, Sarcoidosis, Insulin-like growth factor-I

SARCOIDOSIS is a chronic inflammatory disease of unknown etiology. Over $90 \%$ of patients with sarcoidosis present with pulmonary findings at the time of diagnosis. Extra-pulmonary involvement is common, including the liver, eyes, central nervous system,

Received Dec. 28, 2009; Accepted Jan. 4, 2010 as K09E-370 Released online in J-STAGE as advance publication Jan. 16, 2010 Correspondence to: Seijiro MORI, M.D., Ph.D., Department of Diabetes, Metabolism and Endocrinology, Tokyo Metropolitan Geriatric Hospital, 35-2 Sakae-cho, Itabashi-ku, Tokyo 173-0015, Japan. E-mail: seimori1106@gmail.com lymph nodes, and joints. It has been reported that hypoglycemia can be one of the manifestations of patients with pituitary/hypothalamic sarcoid infiltrates [1] due to impaired counter-regulation of glucose [2]. However, if it were not for the pituitary/hypothalamic lesion, patients with sarcoidosis would not be expected to have hypoglycemia. Here, we describe a patient with an isolated sarcoidosis of the spleen who had experienced frequent fasting hypoglycemia which completely disappeared after splenectomy. 


\section{Methods}

\section{Western blot analysis}

Serum samples $(0.2 \mathrm{~mL})$ from the patient and a normal subject were extracted with acid-ethanol (12.5\% $2 \mathrm{~N} \mathrm{HCl} / 87.5 \%$ ethanol), neutralized with $0.855 \mathrm{M}$ Tris, and dried in a Speed Vac concentrator (Savant Instruments, Hickville, NY). For immunoblotting, serum extracts were electrophoresed on a $16 \%$ SDSpolyacrylamide gel under non-reducing conditions, and the size-fractionated proteins were then electroblotted onto a nitrocellulose sheet, which was blocked with 5\% (wt/vol) skim milk, and then incubated with a mouse anti-insulin-like growth factor-II (IGF-II) monoclonal antibody (Upstate Biotechnology). After extensive washing, the sheet was incubated with horseradish peroxidase-conjugated anti-mouse IgG, and the complexes were detected using an enhanced chemiluminescence (ECLplus) system (Amersham).

\section{Real-time quantitative reverse transcriptase-poly- merase chain reaction (RT-PCR)}

Total RNA was extracted from the surgically resected sarcoidosis tissue and normal spleen tissue using ISOGEN (Wako, Osaka, Japan), and cDNA synthesized using SuperScript II Reverse Transcriptase (Invitrogen Japan, Tokyo, Japan), Random Primer Hexa-deoxyribonucleotide mixture (TaKaRa, Japan), dNTP Mixture(TaKaRa, Japan) and RNaseOUT Recombinat Ribonuclease Inhibitor (Invitrogen Japan, Tokyo, Japan). IGF-I and IGF-II mRNA level was quantified with real-time quantitative RT-PCR using qPCR Supermix-UDG with ROX (Invitrogen Japan, Tokyo, Japan) following the manufacture's protocol. PCR primers were synthesized by Greiner Bio-one (Tokyo, Japan). The forward and reverse primers for the human IGF-I (Assay ID: Hs01547656_m1) and the human IGF-II (Assay ID: Hs01005963_m1) were used from inventory of TaqMan Gene Expression Assays. As an endogenous control gene, TaqMan Ribosomal RNA Control Reagents (Applied Biosystems, Foster City, CA, USA) was used.

\section{Measurements of serum visfatin and free IGF-I}

Serum concentrations of visfatin and free IGF-I were determined by commercial solid-phase enzyme-linked immunosorbent assay kits (AdipoGen Inc., Incheon, South Korea and Diagnostic Systems Laboratories, Inc., Webster, Texas, respectively). The intra- and inter-assay coefficients of variation for visfatin were $2.3-9.1 \%$ and $4.7-7.2 \%$, respectively. The intra- and inter-assay coefficients of variation for free IGF-I were $3.6-4.8 \%$ and $6.2-11.1 \%$, respectively.

\section{Immunohistochemistry}

The immunohistochemical study was performed by the polymer-based visualization technology using an EnVision Dako ChemMate kit (K5027, Dako, Kyoto, Japan). The paraffin sections were deparaffinized, hydrated, and incubated in primary antibodies according to the protocol provided by the manufacturer. The primary antibodies were a rabbit polyclonal anti-insulin (L1859, Dako), anti-glucagon (L1813), and anti-somatostatin (L1840) antibodies.

\section{Case Report}

A 71-year old woman was admitted to our hospital after experiencing recurrent episodes of cold sweats and palpitation for 5 months. These symptoms developed when she was hungry or early in the morning, and then disappeared after eating. It was found that plasma glucose level was very low $(21 \mathrm{mg} / \mathrm{dL})$ when she experienced the symptoms, but she had not been taking any hypoglycemic agents. She did not smoke or drink and had no family history of endocrine disorders or diabetes.

At the time of admission, she was $143 \mathrm{~cm}$ tall and weighed $43 \mathrm{~kg}$ (body mass index: $19.6 \mathrm{~kg} / \mathrm{m}^{2}$ ). Physical examination was unremarkable and chest films were normal. Biochemical data were all within the normal limits except that serum potassium level was low (Table 1). Endocrinological examination revealed no abnormality in basal blood hormone levels, including GH $(0.54 \mathrm{ng} / \mathrm{mL}), \mathrm{LH}(24.3 \mathrm{mIU} / \mathrm{mL}), \mathrm{FSH}$ (39.8 mIU/mL), PRL (3.8 ng/mL), ACTH $(8.5 \mathrm{pg} /$ $\mathrm{mL})$, TSH $(2.22 \mu \mathrm{U} / \mathrm{mL})$, cortisol $(21.9 \mu \mathrm{g} / \mathrm{dL})$, free triiodothyronine $(3.18 \mathrm{pg} / \mathrm{mL})$ and free thyroxine $(1.20$ $\mathrm{ng} / \mathrm{dL}$ ). Magnetic resonance imaging revealed no abnormality in the pituitary gland and the hypothalamic region. When she experienced the symptoms, venous sampling was performed. Venous sampling indicated that the plasma glucose level was $30 \mathrm{mg} / \mathrm{dL}$ and serum immunoreactive insulin (IRI) as well as C-peptide level was undetectable (Table 1). Thus, insulinoma as well as pituitary/adrenal insufficiency as a cause of her hypoglycemia were excluded.

Abdominal computed tomography showed a mass 
Table 1. Laboratory and endocrine data before and after splenectomy

\begin{tabular}{lccc}
\hline Parameter & Before operation & After operation & Reference range \\
\hline Fasting plasma glucose $(\mathrm{mg} / \mathrm{dL})$ & 30 & 91 & $65-110$ \\
Fasting serum IRI $(\mu \mathrm{U} / \mathrm{mL})$ & $<1.0$ & 2.2 & $<17.0$ \\
Fasting serum C-peptide $(\mathrm{ng} / \mathrm{mL})$ & $<0.2$ & 0.6 & $1.1-3.3$ \\
Serum IGFBP-3 $(\mu \mathrm{g} / \mathrm{mL})$ & 1.73 & 1.34 & $1.99-3.20$ \\
Serum IGF-I $(\mathrm{ng} / \mathrm{mL})$ & 116 & 52 & $38-207$ \\
Serum IGF-II $(\mathrm{ng} / \mathrm{mL})$ & 854 & 846 & $414-1248$ \\
Serum potassium $(\mathrm{mEq} / \mathrm{L})$ & 2.5 & 3.5 & $3.5-5.0$ \\
\hline
\end{tabular}

IGFBP-3; insulin-like growth factor binding protein -3 .

in the spleen with a central contrast enhancement effect. The corresponding mass was also detected by gallium-67 scintigraphy. The findings strongly suggested a condition called non-islet cell tumor hypoglycemia (NICTH), however, serum levels of IGF-I and IGF-II were not elevated (Table 1). Serum level of free IGF-I was $0.35 \mathrm{ng} / \mathrm{mL}$ (reference range: 0.110.42). A high molecular weight form of IGF-II [3] was not detected in patient's serum extract by Western blotting (Figure 1). We also found that serum level of visfatin, which had been shown to exert insulinmimetic effects [4], was not elevated; the serum visfatin level was $0.9 \mathrm{ng} / \mathrm{mL}$ (reference range: 1-10). Serum level of insulin autoantibodies, high levels of which also might be a causative factor for hypoglycemia [5], was less than $0.4 \%$ (reference range: $<0.4 \%$ ). Likewise serum insulin receptor autoantibodies [6] were not detected. In addition, serum level of proinsulin was $8.6 \mathrm{pmol} / \mathrm{L}$ (reference range: 6.4-9.4).

Although we failed to obtain firm evidence that the splenic mass was producing substance(s) which could cause hypoglycemia, a diagnostic as well as possibly therapeutic splenectomy was obviously required. She underwent operation; the splenic mass was completely resected surgically. Postoperative course was uneventful. Plasma glucose levels increased to $94 \mathrm{mg} /$ $\mathrm{dL}$ just after operation and remained between 92-173 $\mathrm{mg} / \mathrm{dL}$ even after cessation of continuous glucose infusion. She had no hypoglycemic episodes thereafter. Postoperatively, fasting plasma glucose, serum IRI and serum C-peptide increased, as expected (Table 1). Serum potassium also returned to normal level. Notably, serum level of IGF-II did not appreciably change, while that of IGF-I decreased by half the preoperative level (Table 1).

As shown in Figure 2A, the spleen had a sol-

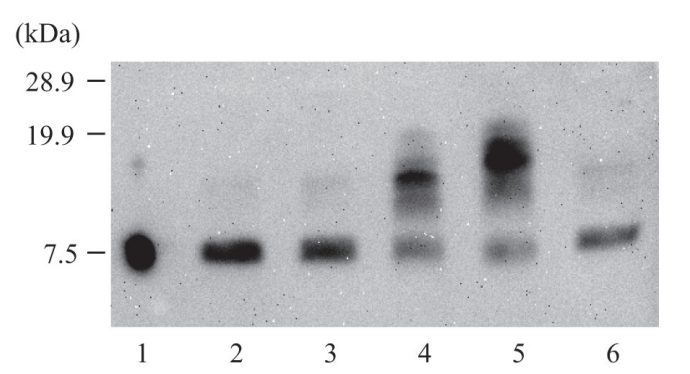

Fig. 1. Western immunoblot analysis of IGF-II. Lane 1, IGFII control; lane 2, patient's serum, preoperative; lane 3, patient's serum, postoperative; lane 4-5, sera from NICTH patients; lane 6 , healthy control serum.

id, elastic hard mass $(6.0 \times 5.7 \times 6.0 \mathrm{~cm}$ in size $)$. Pathological examination revealed numerous non-necrotizing epithelioid granuloma with Langerhans-type multinucleate giant cells (Figure 2B). The splenic hilar lymph nodes showed the same granulomatous inflammation. The acid-fast or Grocott staining was negative. These findings were characteristic of sarcoidosis. Immunoreactivity against somatostatin, insulin or glucagon was not detected in the sarcoidosis tissue by immunohistochemical analysis (Figure 2C). As shown in Figure 3, steady-state mRNA levels of IGF-I and IGF-II in the sarcoidosis tissue were about 1.8-fold greater than and 80-fold less than those in the normal spleen tissue, respectively.

\section{Discussion}

Our present observation was that a patient with an isolated sarcoidosis of the spleen experienced insulinindependent hypoglycemia, and the symptom disappeared after splenectomy. It was most possible that the splenic sarcoid lesion produced some substance(s) 

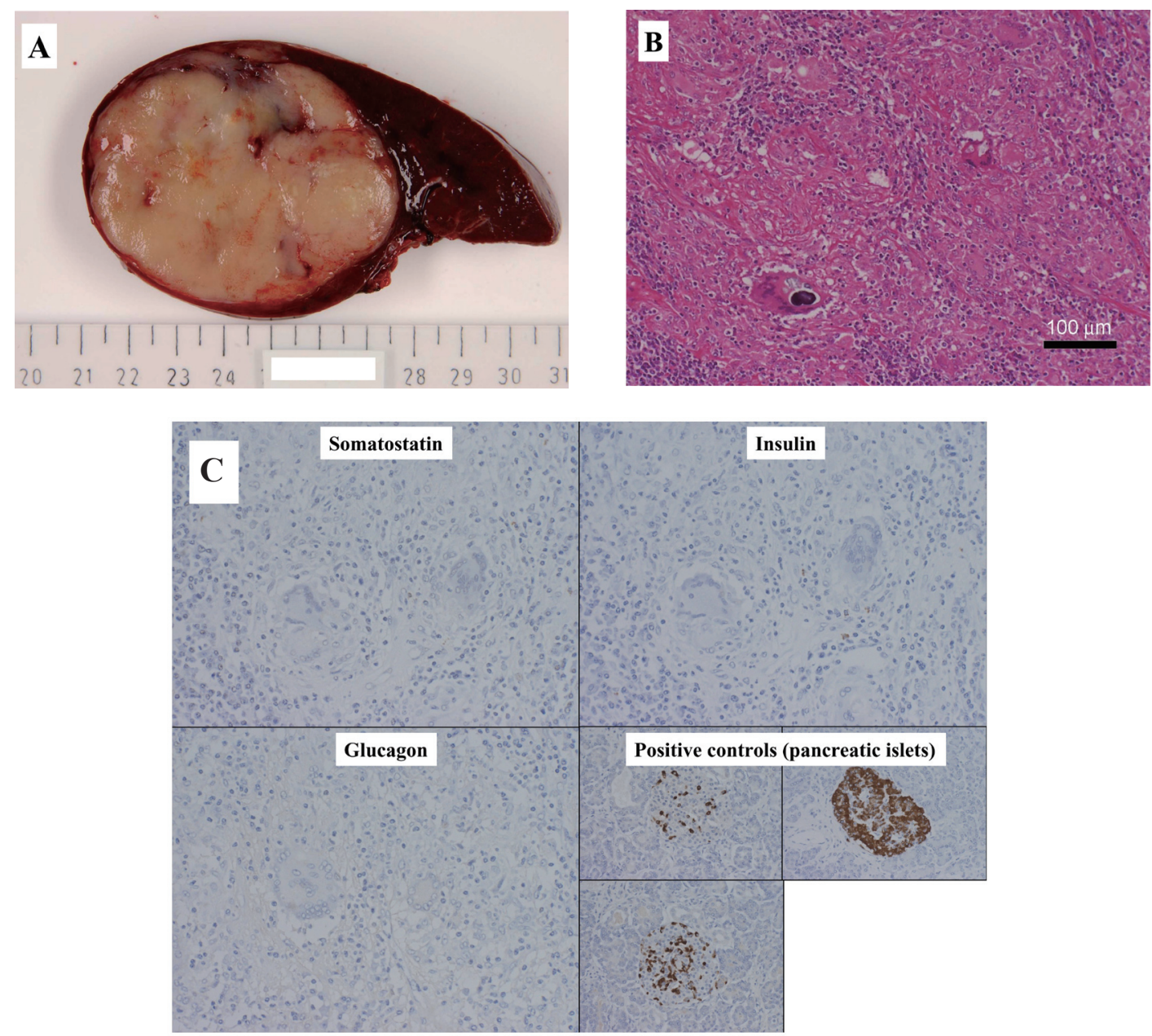

Fig. 2. Cut section of the spleen. (A) Gross appearance: a well-demarcated, yellow-white, solid mass $(6.0$ x 5.7 x $6.0 \mathrm{~cm}$ in size). (B) Microscopic appearance: non-necrotizing granulomatous inflammation with Langerhans-type multinucleate giant cells. The giant cells contain intracellular calcification (Schaumann body). HE stain. (C) Immunohistochemistry: immunoreactivity against somatostatin (upper left), insulin (upper right) and glucagon (lower left) is not detected in the sarcoidosis tissue.

which could cause hypoglycemia. However, serum level of IGF-II was not elevated and, more importantly, the high molecular weight form of IGF-II was not detected (Figure 1). Likewise serum levels of IGF-I and free IGF-I were within reference range, but after splenectomy, the IGF-I level decreased by half the preoperative level (Table 1). RT-PCR revealed that IGF-I mRNA level in the sarcoidosis tissue was about 1.8 -fold greater than that in the normal spleen tissue (Figure 3).

One case report has described a patient with recurrent hypoglycemia due to paraneoplastic secretion of IGF-I by metastasizing large-cell carcinoma of the lung [7]. In this case, total and free serum IGF-I was increased $(692 \mathrm{ng} / \mathrm{mL}$ and $27.2 \mathrm{ng} / \mathrm{mL}$, respec- tively), and after chemotherapy with carboplatinum/ etoposide, the lung nodules largely regressed, and serum IGF-I became normal. Our present case, however, showed relatively low serum IGF-I level which was not expected to cause hypoglycemia under the ordinary conditions [8]. Anatomically, IGF-I produced by the splenic sarcoidosis goes directly to the liver via the portal vein. Although we could not find a precise measurement of hepatic extraction rate of IGF-I in the literature, that of insulin is reported to be about $70 \%$ in the basal state [9]. Therefore, it is possible that, after hepatic extraction and dilution in the systemic circulation, IGF-I concentration might be substantially reduced in the peripheral vein where we measured and, hence, the concentration of IGF-I in the portal 
A. IGF -I

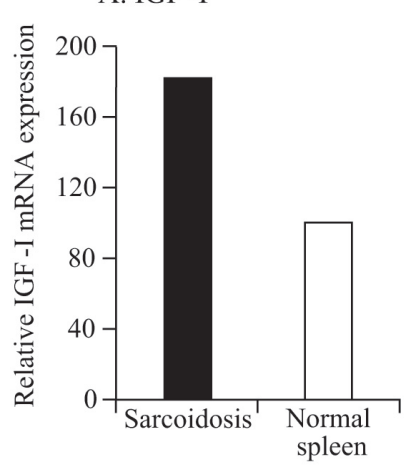

B. IGF-II

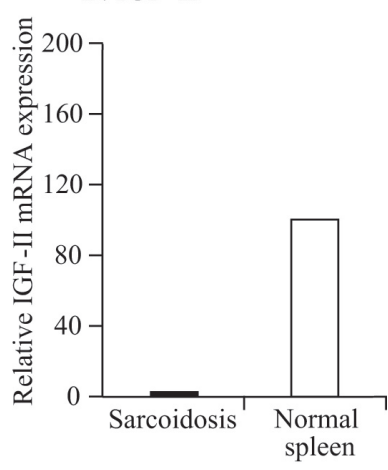

Fig. 3. Expression of IGF-I and IGF-II genes in sarcoidosis and normal spleen tissues. Expression of (A) IGF-I mRNA and (B) IGF-II mRNA in sarcoidosis and normal spleen tissues as determined by RT-PCR is shown as the ratio of each mRNA to that of rRNA.

vein might be much higher than that in the peripheral vein, which was sufficient to suppress hepatic gluconeogenesis in the present case. Furthermore, it seems also possible that partial hypopituitarism might facilitate the onset of hypoglycemia in this patient since basal levels of GH and ACTH were relatively low. Unfortunately, the patient denied further examination to evaluate pituitary GH and ACTH reserve, and the possibility has remained to be elucidated.

It has been shown that the localization of activated immune cells, primarily activated oligoclonal CD4+ $\mathrm{T}$ cells and macrophages together with the release of various pro-inflammatory cytokines and growth factors such as IGF-I, determines the immune phenom- ena as well as the development and fate of the sarcoid granuloma [10]. In pulmonary sarcoidosis, increased level of IGF-I released from activated alveolar macrophages is considered to stimulate collagen synthesis by pulmonary fibroblasts [11]. It is, thus, quite reasonable that an extra-pulmonary sarcoid granuloma, such as sarcoidosis of the spleen found in the present case, could also produce IGF-I.

Isolated granulomatous disease confined to the spleen is rare. Currently, the literature documents only four prior cases of sarcoidosis presenting with isolated splenic lesions $[12,13]$. Usually, splenectomy and subsequent histopathologic examination are required for definitive diagnosis as well as neoplastic exclusion. Once diagnosed, patients require continual follow-up for systemic manifestations and associated complications of sarcoidosis. So far, hypoglycemia has not been reported in these 4 cases.

Finally, it should be noted that some unknown factor(s) secreted by the sarcoidosis tissue might cause hypoglycemia through insulin-independent mechanism in our patient. But, at present, the hypoglycemia appeared to be due mainly to ectopic secretion of IGF-I. Further study is necessary to solve an enigma.

\section{Acknowledgments}

We wish to express our sincere thanks to Mrs. Aki Watanabe, Chiba University Graduate School of Medicine, for assistance with the measurements of serum visfatin and free IGF-I in the present study.

\section{References}

1. Jawadi MH, Hanson TJ, Schemmel JE, Beck P, Katz FH (1980) Hypothalamic sarcoidosis and hypopituitarism. Horm Res 12: 1-9.

2. Féry F, Plat L, van de Borne P, Cogan E, Mockel J (1999) Impaired counterregulation of glucose in a patient with hypothalamic sarcoidosis. N Engl J Med 340: 852-856.

3. Fukuda I, Hizuka N, Ishikawa Y, Yasumoto K, Murakami Y, Sata A, Morita J, Kurimoto M, Okubo Y, Takano K (2006) Clinical features of insulin-like growth factor-II producing non-islet-cell tumor hypoglycemia. Growth Horm IGF Res 16: 211-216.

4. Xie H, Tang SY, Luo XH, Huang J, Cui RR, Yuan LQ, Zhou HD, Wu XP, Liao EY (2007) Insulin-like effects of visfatin on human osteoblasts. Calcif Tissue Int 80: 201-221.

5. Uchigata Y, Hirata Y (1999) Insulin autoimmune syndrome (IAS, Hirata disease). In: Eisenbarth G (ed) Endocrine and organ specific autoimmunity. RG Landes, Austin: 133-148.

6. Rodriguez O, Collier E, Arakaki R, Gorden P (1992) Characterization of purified autoantibodies to the insulin receptor from six patients with type B insulin resistance. Metabolism 41: 325-331.

7. Nauck MA, Reinecke M, Perren A, Frystyk J, Berishvili G, Zwimpfer C, Figge AM, Flyvbjerg A, Lankisch PG, Blum WF, Klöppel G, Schmiegel W, Zapf J (2007) Hypoglycemia due to paraneoplastic se- 
cretion of insulin-like growth factor-I in a patient with metastasizing large-cell carcinoma of the lung. J Clin Endocrinol Metab 92: 1600-1605.

8. Guler HP, Zapf J, Schmid C, Froesch ER (1989) Insulin-like growth factors I and II in healthy man: estimations of half-lives and production rates. Acta Endocrinol 121: 753-758.

9. Toffolo G, Campioni M, Basu R, Rizza RA, Cobelli C (2006) A minimal model of insulin secretion and kinetics to assess hepatic insulin extraction. Am J Physiol Endocrinol Metab 290: 169-176.

10. Kunkel SL, Chensue SW, Strieter RM, Lynch JP, Remick DG (1989) Cellular and molecular aspects of granulomatous inflammation. Am J Respir Cell Mol
Biol 1: 439-447.

11. Allen JT, Bloor CA, Knight RA, Spiteri MA (1998) Expression of insulin-like growth factor binding proteins in bronchoalveolar lavage fluid of patients with pulmonary sarcoidosis. Am J Respir Cell Mol Biol 19: 250-258.

12. Zia H, Zemon H, Brody F (2005) Laparoscopic splenectomy for isolated sarcoidosis of the spleen. $J$ Laparoendosc Adv Surg Tech A 15: 160-162.

13. Giovinale M, Fonnesu C, Soriano A, Cerquaglia C, Curigliano V, Verrecchia E, De Socio G, Gasbarrini G, Manna R (2009) Atypical sarcoidosis: case reports and review of the literature. Eur Rev Med Pharmacol Sci 1: 37-44. 